\title{
Treatment of carpal tunnel syndrome
}

\section{( Leczenie zespołu cieśni kanału nadgarstka )}

\author{
Jarosław Strychar 1,A,D , Zbigniew Kopański 2,E,F , Gregory Sianos 3,B,D,C , \\ Adelaida Maria Castro Sanchez ${ }^{4, E}$
}

\begin{abstract}
Introduction. In the literature one can find descriptions of many methods that concern both conservative and surgical treatment of the carpal tunnel syndrome (CTS). Similarly, the effectiveness of these methods is assessed differently.

The aim of the study. The main objective of the thesis was to discuss the methods of conservative and surgical treatment of CTS.

Selection of material. The search was carried out in the Scopus database using the concepts of the carpal tunnel syndrome, methods of surgical treatment, conservative treatment and complications after treatment of patients with CTS in years 2000-2018. The literature found in the Google Scholar database was analysed in terms of the largest number of citations. Literature selected in this way served as the material for the thesis.

Conclusions. Prophylaxis, diagnostics and, above all, therapy implemented in patients with CTS are of great importance in the disease prognosis. The validity of this statement may seem obvious, although it is not always noticed by the patients themselves or even doctors. Prognosis in the case of people with CTS may be established in relation to the progress of the undertaken treatment and the physical condition of the patient in the long-term perspective.
\end{abstract}

Key words - carpal tunnel syndrome, surgical treatment, physical therapy, TENS, neuromoblisation.

Streszczenie - Wstęp. W literaturze przedmiotu można znaleźć opisy wielu metod, które dotyczą zarówno zachowawczego, jak również operacyjnego leczenia zespołu kanału nadgarstka (carpal tunnel syndrome - CTS). Podobnie różnie jest oceniana skuteczność tych metod.

Cel pracy. Celem pracy było omówienie metod zachowawczego i operacyjnego leczenia CTS.

Dobór materiału. Poszukiwania przeprowadzono w bazie Scopus używając pojęć zespół kanału nadgarstka, metody leczenia operacyjnego, leczenie zachowawcze, powikłania po leczeniu chorych z CTS za okres 2000-2018r. Znalezione piśmiennictwo w bazie Google Scholar przeanalizowano pod kątem największej liczby cytowań. Tak wyselekcjonowane piśmiennictwo posłużyło za materiał do opracowania niniejszej pracy.

Wnioski. Profilaktyka, diagnostyka, ale przede wszystkim wdrożona terapia u chorych CTS ma bardzo duże znaczenie w rokowaniu w tej chorobie. Zasadność tego stwierdzenia może wydawać się oczywista, choć nie zawsze jest ona zauważana przez samych pacjentów, a nawet lekarzy. Rokowania w przypadku osób z CTS mogą dotyczyć prognozy w odniesieniu do postępów podjętego leczenia oraz kondycji fizycznej chorego w szerokiej perspektywie czasu.

Stowa kluczowe - zespół kanału nadgarstka, leczenie operacyjne, fizykoterapia, TENS, neuromoblizacja.

\section{Author Affiliations:}

1. Collegium Masoviense - College of Health Sciences, Poland

2. Faculty of Health Sciences, Collegium Medicum, Jagiellonian University, Poland

3. Glasgow Royal Infirmary, United Kingdom

4. University of Almería, Spain

Authors' contributions to the article:

A. The idea and the planning of the study

B. Gathering and listing data

C. The data analysis and interpretation

D. Writing the article

E. Critical review of the article

F. Final approval of the article

\section{Correspondence to:}

Prof. Zbigniew Kopański MD PhD, Faculty of Health Sciences, Collegium Medicum, Jagiellonian University, Piotra Michałowskiego 12 Str., PL- 31-126 Kraków, Poland, e-mail: zkopanski@o2.pl

Accepted for publication: May 06, 2019.

\section{METHODS OF TREATMENT OF THE CARPAL TUNNEL SYNDROME}

$\mathrm{I}^{\mathrm{n}}$ $\mathrm{n}$ the subject literature one can find descriptions of many methods that concern both conservative and surgical treatment of the carpal tunnel syndrome (CTS). The use of conservative (non-surgical) methods should give first re- 
sults after a period of about two weeks, while the whole treatment lasts about 6 months. In the case of surgical treatment, the transverse ligament of the wrist is divided. The first effects of this treatment can be experienced more or less the next day after the operation. In the literature, the opinions on the value of CTS treatment methods are very diverse. $[1,2]$

The aim of the study was to discuss the methods of conservative and surgical treatment of CTS.

\section{SELECTION OF MATERIAL}

The search was carried out in the Scopus database using the concepts of the carpal tunnel syndrome, methods of surgical treatment, conservative treatment and complications after treatment of patients with CTS in years 20002018. The literature found in the Google Scholar database was analysed in terms of the largest number of citations. Literature selected in this way served as the material for the thesis.

\section{CTS CONSERVATIVE TREATMENT}

The main objective of therapeutic procedure in patients with CTS is elimination of pain, improvement of sensation and hand functioning. The most common method of conservative CTS treatment is pharmacotherapy and physiotherapy. [3-6]

Pharmacotherapy includes [7]:

- non-steroidal anti-inflammatory drugs (NLPZ),

- supplementation of vitamin B6,

- steroid therapy,

- diuretics.

The clinical tests have demonstrated that the practical efficacy of vitamin B6 in the reduction of CTS symptoms is insignificant and falls within the scope of the placebo effect. Administration of oral steroids (steroid therapy) has a higher efficacy than the use of non-steroidal antiinflammatory drugs. The use of diuretics also gives good results, although according to some authors, they are too short-term and consist mainly in improving the hand function and reducing the clinical symptoms of CTS. In addition to the positive therapeutic effects of the above mentioned medications, one should be aware of the danger of some complications they might bring. [8,9]
Steroids are also given in the form of injections, however their administration directly to the carpal tunnel may result in complications causing damage to the median nerve. It is also emphasised that repeated injections into the carpal tunnel do not improve the patient's condition, therefore it is advisable to administer this drug only once. At the same time, there is currently no convincing evidence of positive effects of steroid injections over a long period of time. In addition, there was no proved predominance of the described form of therapy over cases in which patients with CTS were treated with the use of orthopaedic equipment, laser therapy, or anti-inflammatory drugs. However, according to some authors, steroid intrathecal injections (carpal tunnel) are more effective than oral steroid therapy. [10-15]

In patients with CTS, it is also possible to immobilize the upper limb (in the plaster splint or palm orthosis) and to implement physiotherapy. Among the wrist orthoses and stabilizers are short orthoses, elastic stabilizers, long orthoses and finger orthoses, which are made in the anatomical shape, thanks to which they stabilize the wrist joint, wrist and forearm of the patient. The main purpose of the orthopaedic equipment is to immobilize the limb in the radial-wrist joint and stabilize it in a neutral or straight position, with the dorsal flexion maintained within 10 to 30 degrees. In addition to pharmacotherapy and mechanical immobilisation of the upper limb, physiotherapy can also be used in CTS patients, including [7,16,17]:

- laser therapy,

- ultrasounds,

- transcutaneous electrical nerve stimulation - TENS,

- ionophoresis,

- elements of kinesitherapy, which include neuromobilisation and sliding exercises of the median nerve.

The effectiveness of the described treatments has been fully confirmed by many years of clinical observations. [7,9]

CTS patients are also treated with the use of kinesitherapy elements that include neuromobilisation and sliding exercises of the median nerve. Kinesitherapy is defined as therapeutic gymnastics, which is based on physical exercises treated as an important therapeutic agent that affects the condition of the body. Thanks to systematic exercises, in many cases it is possible to restore proper mobility in the joints and the right endurance of the muscles. Depending on the needs, the main goal of kinesitherapy may consist in restoring the patient's physical fitness, adapting to functioning in the event of permanent disability, as well as 
preparing the patient for further rehabilitation by means of movement exercises.

Generally, it can be assumed that the most important common feature connecting the above mentioned therapeutic methods is their analgesic, anti-inflammatory, antiswelling and regenerative effect. Physiotherapy is often very beneficial not only to the damaged median nerve, but also to the surrounding soft tissues, and can therefore become a very important supporting element after the surgery. $[3,7,19]$

\section{SURGICAL TREATMENT}

In the case of surgical treatment in people who suffer from ailments directly related to CTS, the division of transverse ligament of the wrist is used to decompress the median nerve. The procedure can be performed both by the open method or endoscopic method, as well as by the method of the so-called "small cuts".

Surgery is performed under conduction anaesthesia of the median nerve at the level of the wrist or in axillary block under intravenous regional or local anaesthesia. [2]

\section{Open method}

Most often, the procedure is performed using the open method, which involves cutting the transverse ligament of the wrist under strict visual inspection of the operating surgeon (Figure 1,2,3,4,5).

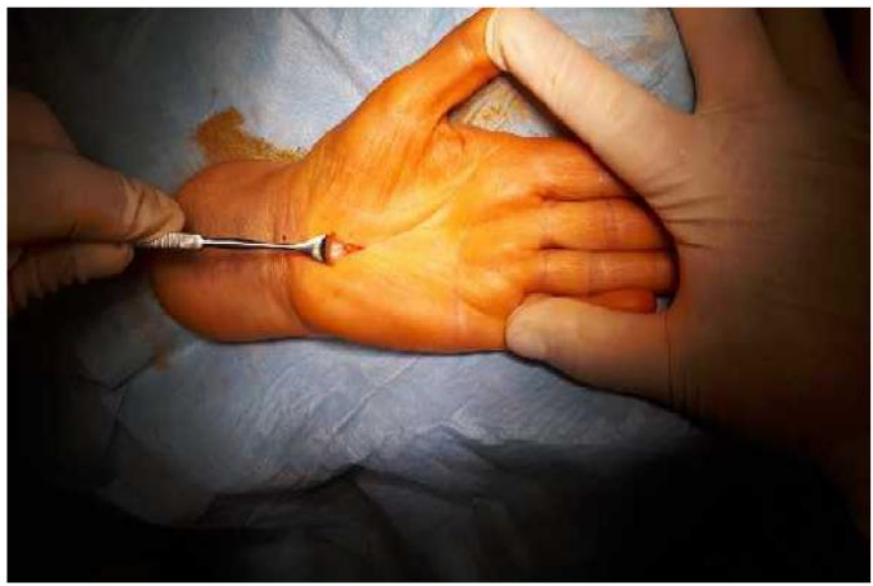

Figure 1. Traditional method (J. Strychr's material)

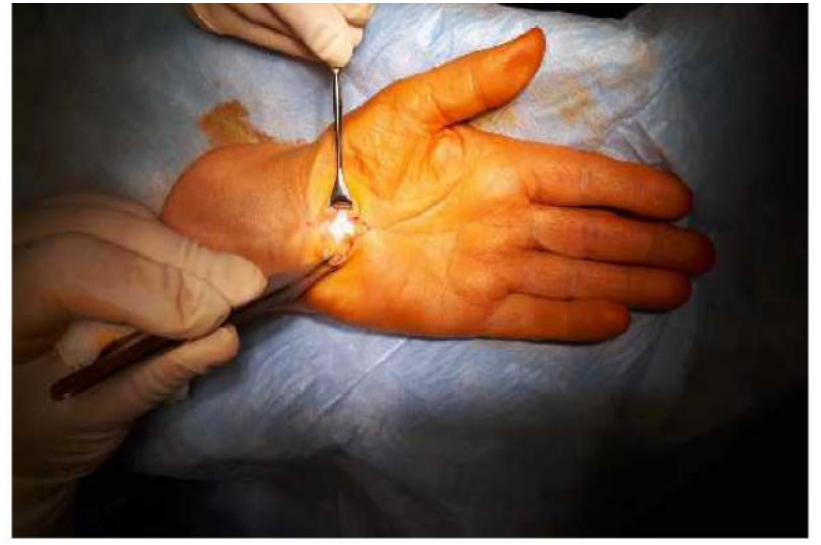

Figure 2. Transverse ligament of the wrist (J. Strychr's material)

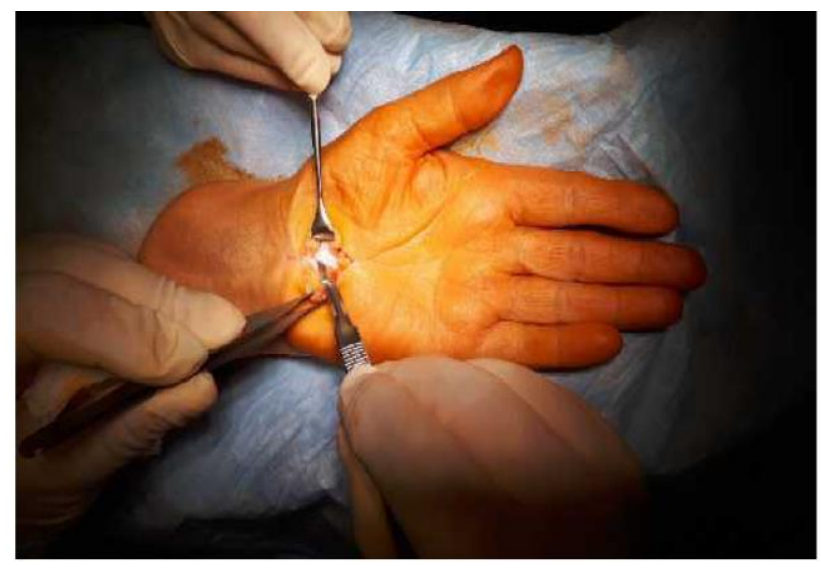

Figure 3. The place of incision of the transverse ligament of the wrist (J. Strychr's material)

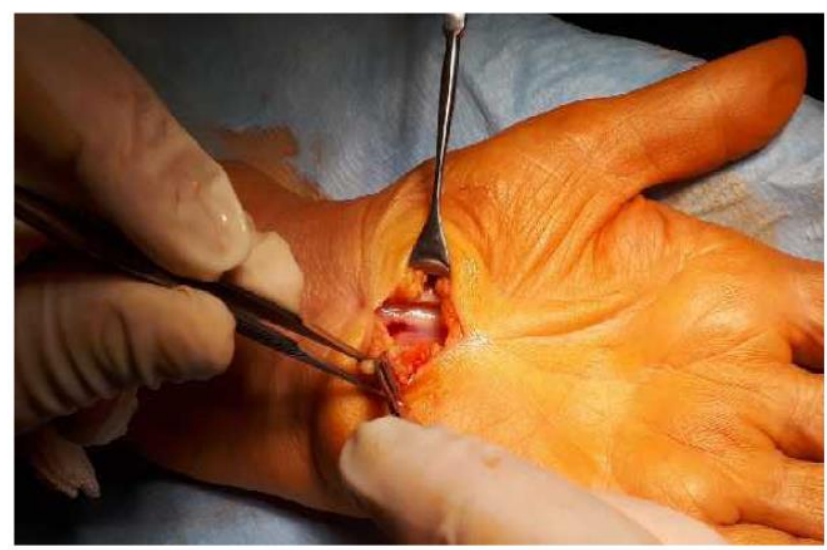

Figure 4. The bloodied median nerve (J. Strychr's material) 


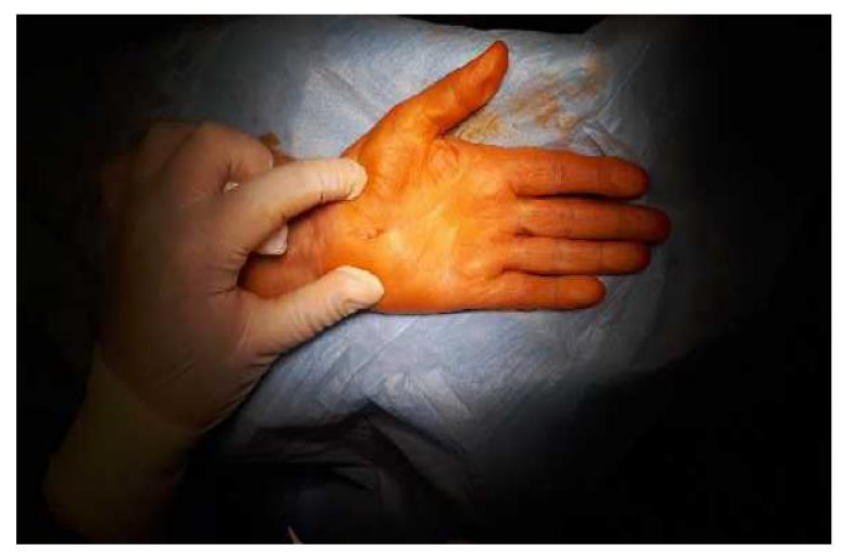

Figure 5. Minimal invasive method, small cuts (J. Strychr's material)

Nevertheless, the surgery itself can bring many complications. These complications include [7,20-22]:

- the possibility of incomplete cutting of the flexor retinaculum,

- neuropraxia or possible damage to the median nerve, mainly its ascending motor branch;

- the possibility of damage to the palmar dermal nerve,

- possibility of damage to the superficial palmar nerve or the ulnar artery arch,

- unintentional crossing of Guyon's tunnel.

Complications associated with CTS surgery may also develop later. They concern, for example, the tenderness of the scar, the loss of the original strength of the grip and the occurrence of hand pains. The scar is initially tender and delicate, which is why it can be easily damaged. Scars, as a permanent trace of surgery/ injury, may be an aesthetic problem for some people, especially when they are in a visible place. [2,23-25]

\section{Endoscopic method}

The endoscopic method for the treatment of CTS was first used in 1989 in Japan. However, due to its specificity, this method requires highly specialised instruments. Endoscopic surgery in the CTS treatment is usually carried out with one or two surgical approaches. Initially, two operational approaches were used, the first of which was located at the level of the transverse fold of the wrist, while the second in the part located closer to the metacarpus. Later, the method was modified to one operational access located on the border connecting the forearm and the wrist. The use of this method increased the effectiveness of the opera- tion to $96.5 \%$, while reducing the risk of developing complications to $2.7 \%$. [26-28]

The most frequently reported complications that occur during surgery include [20,29]:

- paraesthesia, which may appear in the area innervated by the median nerve or the ulnar nerve,

- partial (incomplete) release of the flexor retinaculum,

- cutting the tendons of the flexor muscles,

- damage to the arterial palm arch.

Proponents of the endoscopic method emphasise that the shorter the surgical wound, the lower the risk of subsequent pain in the patient, which facilitates faster recovery of the hand efficiency. In turn, the opponents of this method emphasise that during the procedure, a smaller insight into the operating field is generated, which increases the risk of more complications; they also indicate high costs of treatment with this method. [30-32]

According to many authors, one should not decide on minimally- invasive methods in a situation where it is absolutely necessary to review the environment of the nerve. This applies in particular to patients with traumatic carpal tunnel syndrome, patients suffering from rheumatoid arthritis, patients with lumps within the carpal tunnel, as well as reoperation situations. [20,33-35]

At the same time, it should be emphasised that so far there is no proof of the existence of more effective or superior operational methods than the others.

It can be assumed that the decision on a particular method of surgical treatment should be dictated both by the skills of the operator (surgeon) and the expectations of the patient himself. [20,32]

The method of "short (small) cuts" is considered to be the youngest surgical technique used to treat CTS. This technique also has advantages and disadvantages. Initially, the operator made a section of the flexor retinaculum using two separate incisions. The first longitudinal incision was made on the metacarpus, and the second transverse incision in the wrist itself. After some time, the incision performed within the wrist was given up. After the operation, the wrist may be immobilised in a proper splint, however, the practical benefits of this procedure do not seem to be too certain. The main causes of the failure of CTS surgical treatment include: incorrect diagnosis (double crush syndrome), partial decompression of flexor retinaculum and intraoperative damage. [24,36]

Reoperation is usually considered when a patient develops ailments similar to the pre-operative ones or when there is no apparent improvement in the condition of the upper extremity. In this situation, an open method of CTS 
treatment is recommended, the effectiveness of which is from 50 to $70 \%$. [7]

CTS surgical treatment also requires post-operative rehabilitation, the aim of which is to restore the patient's normal hand function in the shortest possible time, which allows the patient to quickly return to work and enhances the necessary efficiency of everyday activities. Rehabilitation also makes it possible to reduce pain and other troublesome symptoms (paraesthesia, oedema), to enhance the muscular strength of the hand and significantly improve the range of movements performed in the radial-carpal joint. An important effect of rehabilitation is the desensitisation and elasticity of post-operative scar. Within a few hours after the surgery, when the anaesthetic drugs stop working, the patient begins to feel pain, and then the swelling of the operated area appears. It is advisable to hold the hand in a higher position, which reduces swelling and accelerates wound healing. If the patient performs a sedentary job, which does not require excessive loading of the operated limb, he can return to his professional duties after 3-4 weeks. If the work is of a physically heavy and functional nature and it absorbs hands, the period of rehabilitation should last from 8 to 12 weeks. The process of improving the patient after the CTS operation usually takes a few weeks, however, considering the severity of the disease and the patient's involvement the recovery period can be extended to 9 months. After the procedure, basic starting exercises preceded by baths are usually sufficient. Immediately after the sutures are removed, patients are advised to have their morning hand baths in warm water with the addition of a water surface tension-reducing agent (soap) for about 10-15 minutes. While bathing, it is recommended to perform slow movements, which during the first 2-3 days, include bending, straightening, stretching and pinching of the fingers, and from the 3rd to 4th day, the wrist's gravity movements consisting of free falling are introduced. From the 5th to 6th day, the patient should start performing active exercises with the resistance consisting, for example, in squeezing the sponge, so as to squeeze the water out. The above set of exercises is sufficient for the patient to achieve similar fingers and wrist mobility as before the procedure, and in a situation where after 7-10 days of exercise there is no return of the original function, institutional rehabilitation should be considered. [3,37]

\section{PROGNOSIS}

Prophylaxis, diagnostics, as well as implemented therapy in CTS patients and prognosis are extremely interrelated and mutually dependent. The validity of this statement may seem obvious, although it is not always noticed by the patients themselves and even doctors. Prognosis in the case of people with CTS may refer to the progress of the undertaken treatment and the physical condition of the patient in the long term, which is based on systematic research and observation of the patient.

One of the important factors of bad prognosis is a delayed diagnosis of the disease, which often arises from the fault of the patient himself and/or his immediate environment. However, the correct diagnosis of CTS may sometimes prove to be extremely difficult. It is often difficult to determine the disease in its initial period.

Based on the diagnosis, symptomatic treatment is implemented, which mainly involves the immobilisation of the upper extremity, as well as administration of analgesic and anti-inflammatory drugs, steroid injections and physiotherapeutic treatments. In the case of insufficient effects of conservative treatment, surgical treatment is necessary to release (decompress) the median nerve.

Recurrence of CTS may occur both after the implementation of conservative treatment and surgical treatment, which concerns in particular those cases in which the immediate cause of the disease has not been completely eliminated. It should be emphasised that discontinuation of treatment in the case of people with CTS inevitably leads to irreversible damage of the median nerve and causes significant limb disfunctions. As a result, the patient may be permanently disabled and thus be unable to perform his professional duties. [38-40]

\section{POST-OPERATIVE REHABILITATION}

Rehabilitation used in patients after decompression of the median nerve includes physiotherapeutic treatment, the aim of which is to bring the patient back to his/her full physical fitness as soon as possible. Recovery after surgery, depending on its course and nature, can last from a few to a dozen of weeks. After surgery, patients are significantly weakened, therefore they are recommended to reduce physical effort and lead a well-balanced lifestyle. Determining the exact time of rehabilitation after CTS surgery is extremely difficult, because the improvement of the patient depends on many different factors. They include both the type of performed surgery (open method or endoscopic method), the severity of lesions, as well as the patient's immunity and his/her physical predispositions. [4042] 


\section{PHYSIOTHERAPY METHODS USED AFTER CTS OPERATIONS}

Among the most popular methods that are used in the rehabilitation of patients after CTS surgery, physiotherapy (electrostimulation, massages, mobilisation of joints) and kinesitherapy are mentioned. Physical therapy is one of the most popular forms of physiotherapy in which the patient's body interacts with many different physical stimuli.

The most important function of physiotherapy in the case of patients who have undergone the decompression of the median nerve consists in reducing the pain at night, as well as improving the hand function. The therapy also improves the elasticity of the connective tissue and acts as an analgesic. The interaction of ultrasound with nerve tissue increases the temperature of the nerves, increasing the rate of conduction of nerve impulses and the permeability of cell membranes and improves cellular metabolism. Ultrasonication also influences the increase of blood flow through the treated area and has a positive effect on the synthesis of fibroblasts and collagen, leading to the inhibition of inflammatory processes and increasing the pain threshold. Patients after decompression of the median nerve can also undergo kinesitherapy. For this purpose, they perform specific exercises in series, while increasing their intensity. They consist primarily in stretching the flexors. [3,42,43]

\section{ELECTROSTIMULATION WITH TENS}

Electrostimulation with TENS (Transcutaneous Electrical Nerve Stimulation), or percutaneous nerve stimulation, is a clinically proven, non-invasive and nonpharmacological analgesic therapy method that is applicable to patients following decompression of the median nerve. It is extremely effective in relieving chronic and acute pain. The method uses electrostimulators that send low-amplitude electrical impulses through the skin directly to the peripheral nerves of the patient. Using these nerves, the electrical signal/ information reaches the synaptic connections of the patient's spinal cord, where on the one hand it blocks (pain gating) a nerve impulse carrying pain information to the brain, and on the other hand- produces natural analgesic substances. The signal blocking the nerve impulse causes that the patient's brain does not receive information about the place and intensity of pain. ${ }^{1}[44,45]$

In addition to blocking pain impulses, percutaneous nerve stimulation makes the patient's body produce its own analgesics (endorphins), with the force comparable to the potency of morphine and other opioid compounds. [4648]

It is worth emphasising that electrostimulation with TENS currents uses the natural mechanisms of the patient's body that limit the transmission of pain signals. TENS does not cure the causes of pain, but it significantly reduces its sensation and prolongs the analgesic effect. TENS provides therapy at home, which is extremely comfortable for patients after decompression of the median nerve. Thanks to the therapy, it is possible to shorten the period of rehabilitation itself, as well as minimize the risk of posttraumatic complications associated with the patient's movements. An important advantage of TENS electrostimulation is the ability to reduce significantly the amount of administered analgesics (up to 80\%) and to eliminate related adverse reactions as well as to shorten the period of the patient's return to his/her primary physical fitness after the procedure of the median nerve decompression. [44,49-52]

\section{NEUROMOBILISATION OF CENTRAL NERVE}

Neuromobilisation techniques include physiotherapeutic methods relying on movement. Neuromobilisation of the median nerve aims to restore the correct neuromechanics (adaptation of the nervous system to weight changes and mechanical tensions. In this case, it involves stretching (through movement) the nerve trunks, roots and spinal nerves, spinal cord and spinal meninges in the joints of the upper extremity in isolated positions. Neuromobilisation should be undertaken as early as possible in the early stages of the disease, when morphological changes have not yet taken place. [53]

It should cover all tissues that are involved in the development of carpal tunnel pathology (muscles, joints, nerve

1 Gate theory of pain proposed by Melzack and Wall in 1960 describes mechanisms in which electrical stimulation of nerve fibres can reduce pain. The essence of the phenomenon is the impulse saturation at the end of the sensory (tactile) endings of the dorsal core (sensory horn), which can reduce or block the entry of nociceptive (pain) information to the core. The stimulation of the sensory nerves with electrical stimuli makes the information reach the spinal cord faster than the pain stimuli, inhibiting the latter and blocking the stimulation of the central nervous system with pain signals. [44,45] 
trunks, skin and subcutaneous tissue). Neuromobilisation should involve the entire nerve trunk of the median nerve, and its main goal is to improve the neuromechanics of the upper extremity by mobilising peripheral nerves, roots and spinal nerves, spinal meninges and perineural connective tissue. Neuromobilisation techniques aim to restore normal neuromechanics of the peripheral nerves (median nerve) and the central nervous system. Neuromobilisation requires performing preliminary tests, which relate to the assessment of the level of surface sensation, distinguishing the double touch, as well as the proprioceptive sensation (vibration). It is also necessary to assess the function of the indicator muscles, which are innervated from one segment, to examine reflexes having a muscular character, to test the palpation of nerve trunks and check the nerve trunks tone based on tone tests as well as to examine the mobility of nerve trunks based on mobility tests of nerve trunks. The testing allows for a selection of the optimal neuromobilisation technique.

Neuromobilisation techniques used in patients after decompression of the median nerve bring a significant relief, resulting in reduced pain. The neuromobilisation procedure itself, apart from pain reduction, brings a visible improvement in the blood supply of the nervous tissue, decreases the oedema in the nerve tissue, improves axonal transport, reduces the sympathetic tone and helps to restore normal neuromechanics and nerve cell physiology. [54-56]

\section{REFERENCES}

[1] Keith MW, Masear V, Chung KC, Maupin K, Andary M, Amadio PC, Watters WC 3rd, Goldberg MJ, Haralson RH 3rd, Turkelson CM, Wies JL, McGowan R. American Academy of Orthopaedic Surgeons Clinical Practice Guideline on diagnosis of carpal tunnel syndrome. J Bone Joint Surg Am 2009; 91(10): 2478-2479.

[2] Grabb and Smith's Plastic Surgery. London; Lippincott Williams \& Wilkins, 2017.

[3] Viera AJ. Management of carpal tunnel syndrome. Am Fam Physician 2003; 68: 265-272.

[4] Straburzyński G, Straburzyńska-Lupa A. Fizjoterapia. Warszawa; PZWL, 2007.

[5]Afshar A, Yekta Z, Mirzatoluei F. Clinical course of the non-operated hand in patients with bilateral idiopathic carpal tunnel syndrome. J Hand Surg (Am) 2007;32(8): 1166-1170.

[6]Gniadek M, Trybus M. Zespół kanału nadgarstka - etiologia i leczenie. Prz Lek 2016; 73(7): 520-524.

[7]Gerritsen A, Krom de M, Struijs M, Scholten R, Vet de H, Boutner L. Conservative treatment options for carpal tunnel syndrome: a systemic review of randomised controlled trials. J Neurol 2002;249:272-280.

[8] Atroshi I, Gummesson C. Non-surgical treatment in carpal tunnel syndrome. Lancet 2009; 374(9695): 1042-1044.
[9]Piazzini DB, Aprile I, Ferrara PE, Bertolini C, Tonali P, Maggi L, et al. A systematic review of conservative treatment of carpal tunnel syndrome. Clin Rehabil 2007; 21, (4): 299-314.

[10] Marshall S, Tardif G, Ashworth N. Local corticoste-roid injection for carpal tunnel syndrome. Cochrane Database Syst Rev 2007; 2: CD001554.

[11] Aufiero E, Stitik TP, Foye PM, Chen B. Pyridoxine hydrochloride treatment of carpal tunnel syndrome; a review. Nutr Rev 2004; 62: 96-10.

[12] Wong SM, Hui AC, Tang A, Ho PC, Hung LK, et al. Local vs systemic corticosteroids in the treatment of carpal tunnel syndrome. Neurology 2001; 56: 1565-1567.

[13] Habib GS, Badarny S, Rawashdeh H. A novel approach of local corticosteroid injection for the treatment of carpal tunnel syndrome. Clin Rheumatol 2006; 25: 338-340.

[14] Sevim S, Dogu O, Camdeviren H, Kaleagasi H, Aral M, et al. Longterm effectiveness of steroid injections and splinting in mild and moderate carpal tunnel syndrome. Neurol Sci 2004; 25: 48-52.

[15] O'Connor D, Marshall S, Massy-Westropp N. Non-surgical treatment (other than steroid injection) for carpal tunnel syndrome. Cochrane Database Syst Rev 2003; 1: CD003219.

[16] Ginszt A, Kuliński W. Ocena zastosowania zmiennego pola magnetycznego niskiej częstotliwości w leczeniu niezaawansowanych i idiopatycznych postaci zespołu kanału nadgarstka. Balneol Pol 2002; 154: 57-63.

[17] Martins R S, Siqueira M G. Conservative therapeutic management of carpal tunnel syndrome. Arq Neuro-Psiquiat 2017; 75 (11): 819824.

[18] Zwolińska J, Kwolek A, Skrzypiec J. Skuteczność wybranych metod fizjoterapii $\mathrm{w}$ leczeniu zachowawczym zespołu cieśni nadgarstka (zcn). Prz Med Uniw Rzesz 2007; 3: 239-244.

[19] Zembaty A. Kinezyterapia. Kraków; Wydawnictwo Kasper, 2003.

[20] Mathes SJ, Hentz VR. Plastic Surgery. Philidelphia; Saunders Elsevier, 2012.

[21] Górska J, Jedwabiński M, Frankowska-Rutkowska M, Maciejewski M, Grygiel M. Results of surgical treatment of carpel tunnel syndrome by mean of an open and semi-open method. Med Biol Sci 2013; 27(3):17-22.

[22] English JHJ, Gwynne-Jones DP. Incidence of Carpal Tunnel Syndrome Requiring Surgical Decompression: A 10.5-Year Review of 2,309 Patients. J Hand Surg Am 2015; 40(12): 2427-2434.

[23] Loukas M, Louis RG Jr, Stewart L, et al. The surgical anatomy of ulnar and median nerve communications in the palmar surface of the hand. J Neurosurg 2007; May,106(5):887-93.

[24] Scholten RJ, Mink van der Molen A, et al. Surgical treatment options for carpal tunnel syndrome. Cochrane Database Syst Rev 2007; 4: CD003905

[25] Neuhaus V, Christoforou D, Cheriyan T, et al. Evaluation and treatment of failed carpal tunnel release. Orthop Clin North Am 2012; 43(4): 439-447.

[26] Nawrot P, Nowakowski A, Kubaszewski Ł, Rogala P. Zastosowanie metod małoinwazyjnych w operacyjnym leczeniu zespołu kanału nadgarstka i zespołu rowka nerwu łokciowego. Chir Narz Ruchu 2007; 72: 25-28.

[27] Elliott JM. Ultrasound evaluation of patients with carpal tunnel syndrome before and after endoscopic release of the transverse carpal ligament. Clin Radiol 2007; 62: 895-896.

[28] Chen J. Value of superb microvascular imaging ultrasonography in the diagnosis of carpal tunnel syndrome: Compared with color Doppler and power Doppler. Medicine (Baltimore). 2017; 96(21): e6862.

[29] Benson LS. Complications of endoscopic and open carpal tunnel release. Arthroscopy. Arthroscopy 2006; 22:9: 919-924. 
[30] Schnetzler KA. Acute carpal tunnel syndrome. J Am Acad Orthop Surg 2008; 16(5): 276-282.

[31] Spinner RJ, Amadio PC. Compressive neuropathies of the upper extremity. Clin Plastic Surg 2003; 30: 155-73

[32] Kimura J. Electrodiagnosis in Diseases of Nerve and Muscles: Principles and Practice. New York; Oxford University Press, 2001.

[33] Wong KC, Hung LK, Ho PC, Wong JM. Carpal tunnel release. A prospective, randomised study of endoscopic versus limited-open methods. J Bone Joint Surg Br 2003; 85: 863-868.

[34] Nazzi V, Franzini A, Messina G., Broggi G. Carpal tunnel syndrome: matching minimally invasive surgical techniques. Technikal note. J Neurosurg 2008; 108: 1033-6.

[35] Lee Ho J. Intraoperative dynamic pressure measurements in carpal tunnel syndrome: Correlations with clinical signs. Clin Neurol Neurosurg 2016; 140: 33-37.

[36] Strychar J, Żyluk A. Porównanie wyników leczenia zespołu kanału nadgarstka metodą jednego i dwóch małych cięć. Ortop Traumatol Rehabil 2004; 6: 141-146.

[37] Kiwerska-Jagodzińska K, Mikuła W, Iwanowski M. Postępowanie usprawniające po leczeniu operacyjnym zespołu kanału nadgarstka. Post Rehabil 2001; 15: 17-24.

[38] Trybus M, Hładki W, Lorkowski J. Patient satisfaction following carpal-tunnel decompression : a comparison of patients with and without osteoarthritis of the wrist. Int Orthop 2007; 31: 715-716.

[39] Jarvik JG, Comstock BA, Kliot M, Turner JA, Chan L, Heagerty PJ, Hollingworth W, Kerrigan CL, Deyo RA. Surgery versus nonsurgical therapy for carpal tunnel syndrome: a randomised parallelgroup trial. Lancet 2009; 374(9695): 1074-1081.

[40] Kwolek A, Snela S. Rehabilitacja w chorobach i uszkodzeniach obwodowego układu nerwowego. Prz Med Uniw Rzesz 2008;1: 613.

[41] O'Connor D, Daborn C: Rehabilitation treatments following carpal tunnel surgery. (Protocol). Cochrane Database Syst Rev. 2003; 2: CD004158

[42] Boscheinen-Morrin J, Conolly WB. The hand: Fundamentals of Therapy. Berlin; Butter-worth Heinemann, 2001.

[43] Mika T, Kasprzak W. Fizykoterapia. Warszawa; PZWL, 2006.

[44] Baron R. Neuropathic pain: a clinical perspective. Handb Exp Paharmacol 2009;(194):3-30.

[45] Miljanich G, Rauck R, Saulino M. Spinal mechanisms of pain and analgesia. Pain Pract 2013;13(2):114-30.

[46] Bańburski S, Pyszora A, Krajnik M, Budzyński J. Działanie przeciwbólowe przezskórnej elektrycznej stymulacji nerwów o wysokiej częstotliwości (H-F TENS). Badanie pilotażowe chorych z przewlekłymi zespołami bólowymi narządu ruchu. Pol Med Paliat 2006; 5(3): 120-125.

[47] Hughes GS Jr, Lichstein PR, Whitlock D, Harker C. Response of plasma beta-endorphins to transcutaneous electrical nerve stimulation in healthy subjects. Phys Ther 1984; 64(7): 1062-1066.

[48] Kozubski W, Liberski P. Choroby układu nerwowego. Warszawa; PZWL, 2004.

[49] Liana R, Chudański M, Ponikowska I. Prądy TENS, Träberta oraz Kots'a w terapii fizykalnej. Balneol Pol 2008; 50(1): 5-12.

[50] Cheing GL, Luk ML. Transcutaneous electrical nerve stimulation for neuropathic pain. J Hand Surg (Br) 2005; 30(1): 50-55.

[51] DeSantana JM, Walsh DM, Vance C, Rakel BA, Sluka KA. Effectiveness of transcutaneous electrical nerve stimulation for treatment of hyperalgesia and pain. Curr Rheumatol Rep 2008; 10(6): 492-499

[52] Folga B, Radziszewski K. Przezskórna stymulacja elektryczna nerwów (TENS) w leczeniu bólu. Post Med Klin Wojsk 2008; 13(1): 48-51.
[53] Ciechomski J. Wykorzystanie technik terapii manualnej w połączeniu $\mathrm{z}$ fizykoterapią w leczeniu zespołu cieśni kanału nadgarstka. Med Man 2001; 6(3-4): 72-76.

[54] Dwornik M, Białoszewski D, Korabiewska I, Wroński Z. Zasady stosowania neuromobilizacji w schorzeniach narządu ruchu. Ortop Traumatol Rehabil 2007; 9(2): 111-121.

[55] Ellis RF, Hing WA. Neural mobilization: a systematic review of randomized controlled trials with an analysis of therapeutic efficacy. J Man Manip Ther 2008; 16(1): 8-22.

[56] Erel E, Dilley A, Greening J, Morris V, Cohen B, Lynn B. Longitudinal sliding of the median nerve in patients with carpal tunnel syndrome. J Hand Surg (Br) 2003; 28(5): 439-443. 